\title{
Prawo siły jako polityczna konsekwencja naturalizmu - na przykładzie myśli Jeana-Jacques’a Rousseau
}

\author{
Katarzyna HAREMSKA*
}

\begin{abstract}
The law of force as a political consequence of naturalism: on the example of Jean-Jacques Rousseau: Jean-Jacques Rousseau rejected the Enlightenment ideas of reason, equality and progress. He experienced the charm of physical vigour and male causative power. He preached the apotheosis of primal instincts and the cult of strength. Rousseau's historiosophy disavowed the optimistic vision of the Enlightenment and became its main competitor. The philosopher questioned the existing civilization; on its debris he wanted to restore the natural order based on biologically conditioned inequalities.
\end{abstract}

\section{KEYWORDS}

domination; democracy; egalitarianism; social forms; criticism of civilization; Enlightenment; physis; sophists; thymos

* Dr hab., prof. UP, Instytut Filozofii i Socjologii, Uniwersytet Pedagogiczny w Krakowie. E-mail: katarzyna.haremska@up.krakow.pl. 
Zupełnie jakby ktoś zdarł tapety, które pokrywały Przyrodę, pojawi się nagle [...] czysta i niczym nie zepsuta, prymitywna dzicz.

José Ortega y Gasset

\section{FILOZOFIA W OBRONIE PHYSIS}

Prawo ma naturę pozaempiryczną. Bytuje $\mathrm{w}$ dziedzinie norm, a nie zjawisk; w świecie idei, a nie w Platońskiej ,jaskini”. Egzystując w wymiarze idealnym, nie ma bezpośredniego przełożenia na powinności, które odczuwamy w realnym świecie: nie generuje rzeczywiście działających motywów psychicznych ani nie dysponuje skuteczną egzekutywą, Hobbesowskim „mieczem publicznym”. Każde skutecznie działające prawo wymaga naszej gotowości uznania zobowiązań i ich respektowania. Traktujemy jako prawo te reguły, które budzą nasz szacunek; słuchamy osób, które uznajemy za autorytet. Nasza uległość desygnuje władców. To my dajemy moc „naszym panom”. Jeśli damy ją silniejszym, ich siła stanie się w naszych oczach źródłem prawa, zalegalizuje ich uzurpację i skłoni otoczenie do posłuszeństwa.

Już w czasach starożytnych zauważono, że ludzie mają naturalną skłonność do poważania jednostek potężniejszych od siebie i lekceważenia słabszych. W biologicznie rozumianą naturę ludzką wpisany jest szacunek wobec siły i pogarda wobec słabości. Sofiści orientacji physis zaakceptowali tę powszechną u zwierząt społecznych tendencję i uczynili z niej podstawę swego systemu normatywnego. Brutalność przyrody postawili za wzór ludzkiemu społeczeństwu. Kallikles twierdzit: „Z natury przecież wszystko jest brzydsze, co lichsze, więc: doznawanie krzywd” (Platon, 2002: 66 [483 A]). „Natura sama pokazuje, że sprawiedliwie jest, aby jednostka lepsza miała więcej niż gorsza, i potężniejsza więcej niż słabsza [...], aby człowiek silniejszy władał nad słabszym i posiadał więcej niż on" (Platon, 2002: 66 [483 D]). Wraz z siłą jednostki rośnie szacunek otoczenia. Wyjątkowy respekt budzą osoby pozbawione skruputów, obdarzone wielkim apetytem i nieokiełznaną wolą mocy. Jak mówił Trazymach:

jeżeli ktoś nie tylko pieniądze obywateli weźmie, ale jeszcze ich samych podbije i w niewolników zamieni, wtedy, zamiast [...] hańbiących przydomków, spadają na niego gratulacje i wyrazy uwielbienia. Nie tylko ze strony obywateli, ale i z innych stron, gdzie tylko się dowiedzą, że ten człowiek miary zbrodni dopełnił (Platon, 1990: 60 [344 B]).

Powyższy pogląd wyrażał przekonania ogółu. Musiał być w V wieku p.n.e. w społeczeństwie ateńskim do tego stopnia upowszechniony, że Platon nie wahał się włożyć go w usta swego starszego brata, Glaukona: 
Sprawiedliwość [...] jej nie kochają jako dobra, tylko ją cenią dlatego, że nie czują się na siłach, żeby krzywdy wyrządzać (Platon, 1990: 85 [359 B]).

Kto by dostał w ręce taką wolność, a nie chciałby nigdy żadnej krzywdy wyrządzać i nie tykałby tego, co cudze, wydawałby się ostatnim nędznikiem każdemu, kto by go widział, i ostatnim głupcem (Platon, 1990: 88 [360 D]).

Apologia naturalnych ludzkich skłonności wyrażona w powyższych wypowiedziach nie jest bez wpływu na zachowanie nasze i otoczenia. Tego rodzaju idea podsyca pierwotne instynkty i przyzwala na ich ujawnienie. Tłumi ukształtowane w procesie kulturowej inicjacji poczucie wstydu.

Człowiek, który ma żyć jak należy, powinien żądzom swoim puścić wodze, niechaj będą jak największe, i nie powściągać ich. A kiedy będą jak największe, wystarczą wtedy wiosła odwagi i rozsądku, żeby mieć pełno, po brzegi, wszystkiego, ku czemu się żądza kiedykolwiek ruszy (Platon, 2002: 76 [491 E-492 A]).

Bujne, szerokie życie życie, bez hamulca i bez pana nad sobą, byle było skąd, to jest dzielność i szczęście, a ta reszta to świecidełka, to ludzkie konwenanse przeciwne naturze, to głupstwa, o których i mówić nie warto (Platon, 2002: 77 [492 C]).

Naturalizm jest filozoficznym odpowiednikiem populizmu — usuwa bariery stawiane przez tradycję, podważa zastane hierarchie społeczne i prowadzi do kontestacji istniejących norm kulturowych. Rozsadza panujący ład moralny i ustrojowy. Zagraża fundamentom cywilizacji:

Kiedy cywilizacja śródziemnomorska osiągnęła swój najwyższy poziom — to jest około III wieku p.n.e. - pojawili się cynicy. Na wspaniałych dywanach Arystypa stanął Diogenes w zabłoconych sandałach. Cynicy zaczęli się mnożyć, można ich było spotkać na każdym rogu ulicy i we wszystkich sferach społecznych. A przecież cynicy nic innego nie robili, jak właśnie sabotowali ówczesną cywilizację. Byli nihilistami epoki hellenizmu. W nic nie wierzyli i niczego nie tworzyli. Swoją rolę sprowadzali do rozkładania cywilizacji (Ortega y Gasset, 1995: 106-107).

Podobną rolę w XVIII-wiecznej Europie odegrał Jean-Jacques Rousseau. Francuski filozof, na wzór cyników, „sabotował ówczesną cywilizację” i gloryfikował Naturę. Naturalizm, będący istotnym składnikiem jego filozofii, doprowadził go, podobnie jak wcześniej Diogenesa z Synopy, do odrzucenia wstydu, kontestacji norm kulturowych, apoteozy barbarzyństwa, pochwały relacji, jakie panują wśród ludów prymitywnych, i kultu siły ${ }^{1}$.

${ }^{1}$ Niniejszy artykuł opiera się na wybranych aspektach wielowątkowej i pełnej wewnętrznych sprzeczności filozofii Rousseau. Uwypukla stanowisko naturalistyczne, które wydaje się najbardziej trwałym elementem jego pisarstwa - począwszy od pierwszego utworu filozoficznego (Rozprawa o naukach i sztukach, napisana w 1749 roku, wydana w 1750 roku), po ostatni, 


\section{ROUSSEAU NA PARYSKICH SALONACH}

Rousseau przez czternaście lat włóczył się po traktach i bezdrożach Francji, Włoch, Sabaudii, zaznając momentami skrajnej biedy i bezdomności. W 1742 roku, w wieku trzydziestu lat, przybył do Paryża. Bez wykształcenia, majątku czy pozycji społecznej ruszył na podbój paryskich salonów. Jego głównym kapitałem był talent i duże ambicje. Szybko wywalczył sobie pozycję osoby słuchanej, towarzysko atrakcyjnej, zapraszanej. Potrafił skupiać na sobie uwagę. Posłuch zdobywał między innymi dzięki radykalnym poglądom i antysystemowej krytyce. Filozof odrzucał zastany ład społeczno-polityczny. Bezpardonowo atakował warstwy uprzywilejowane oraz elity intelektualne. Obrażał wszystkich, którzy coś znaczyli: arystokrację, uczonych, artystów. Sam niezwykle drażliwy na własnym punkcie ${ }^{2}$, pod koniec życia cierpiący nawet na manię prześladowczą dawał sobie prawo mówienia innym, co o nich sądzi. Zawstydzał reprezentantów klasy wyższej, z których szczodrego wsparcia chętnie korzystał. Wykorzystywał ich dobre maniery, skrępowanie i poczucie winy. Oskarżał otoczenie za krzywdy prawdziwe i urojone, obwiniał je nawet za własne niegodziwoścí

pisany jeszcze dwa miesiące przed śmiercią (Przechadzki samotnego marzyciela, utwór nieukończony, tworzony do kwietnia 1778 roku, wydany w 1782 roku). Ukazuje polityczne konsekwencje naturalizmu Rousseau, pomija zaś twierdzenia sprzeczne z tym stanowiskiem — w szczególności egalitarne deklaracje oraz krytykę prawa siły zawarte w I księdze Umowy społecznej (1762). W odnośnej księdze Rousseau argumentuje, że prawo siły nie istnieje. Określenie „prawo siły” to oksymoron. Ulegamy sile ze strachu, nie z obowiązku. Gdy słabnie sprawcza moc oprawcy, niknie jego władza nad nami. Już nic nas nie powstrzymuje przed ucieczką lub buntem. Mija strach i powraca nasza wolność wyboru i zdolność respektowania ładu prawnego. „Siła jest potęgą fizyczną: nie dostrzegam, co dla moralności może z jej skutków wyniknąć. Ustąpić wobec siły oznacza akt konieczności nie zaś woli; jest to, co najwyżej, akt rozwagi. W jakim znaczeniu może to się stać obowiązkiem? [...] Jeżeli trzeba słuchać przymusowo, nie ma potrzeby słuchać z obowiązku" (Rousseau, 2002: 14).

${ }^{2}$ Rousseau był bardzo czuły na opinię „lepszego towarzystwa” na jego temat: „ta sztuczna namiętność rozpaliła się we mnie, kiedy wiodłem życie światowe” (Rousseau, 1967: 140). Mimo podejmowanych wysiłków do końca życia nie udało mu się zobojętnieć na to, co inni o nim mówią: „Moje starania, żeby zahartować się wobec tych spojrzeń obelżywych i drwiących, są nieprawdopodobne [...]; nie tylko nie osiągnąłem celu, ale nawet nie poczyniłem postępów i mimo wszystkich ciężkich i próżnych wysiłków zostałem równie podatny na niepokoje, na rozpacz i oburzenie, jak byłem poprzednio" (Rousseau, 1967: 143).

${ }^{3}$ Jego choroba rozpoczęła się w 1765 roku po epizodzie obrzucenia kamieniami domu w Motiers (Szwajcaria), w którym mieszkał po ucieczce z Francji. Francję opuścił ze względu na nakaz aresztowania wystawiony po publikacji Umowy społecznej i Emila (oba utwory zostały wydane w 1762 roku). W 1766 roku, w czasie nieudanego pobytu w Londynie na zaproszenie Davida Hume’a, choroba się pogłębiła - pojawiły się halucynacje słuchowe. Mania prześladowcza towarzyszyła filozofowi do końca życia. W jakiejś mierze jej owocem były dialogi Rousseau sędzia Jana Jakuba (ukończone w 1776 roku), będące jego obroną wobec świata.

${ }^{4}$ Poniżej przykładowe fragmenty listów adresowanych do wysoko sytuowanych reprezentantów francuskich elit. Do Guillaume-Chretien de Malesherbes'a, wybitnego prawnika i męża 
Paryż w omawianym okresie był intelektualną stolicą zachodniego świata. Tam wykuwały się progresywne idee równości, racjonalności i postępu. Ludzie pióra abstrahowali od jednostkowych różnic naturalnych i społecznych. Odrzucali perspektywę deprecjonującą słabych, sprowadzającą jakość indywidualnego życia do czynników wymiernych (pochodzenia, zdolności, posiadanych zasobów). Dominowało myślenie filozoficzne, operujące kategoriami wysnutymi nie z obserwacji świata, ale z pracy rozumu: abstrakcyjnymi, ogólnymi i powszechnymi. Na tym tle rodziła się wiara w prawo naturalne (ius naturale) zrównujące w uprawnieniach i godności wszystkich ludzi ${ }^{5}$.

Koncepcje wymyślone w środowisku Encyklopedii promieniowały na francuskie społeczeństwo, wzbudzając we wszystkich warstwach intelektualny ferment. Jak pisał Alexis de Tocqueville: „Polityczne wychowanie wielkiego narodu spoczęło całkowicie w rękach literatów" (Tocqueville, 1994: 161). Ukształtowany wówczas zestaw wartości oraz nową wrażliwość społeczną można uznać za XVIII-wieczny wariant poprawności politycznej. W dobrym towarzystwie nie wypadało tych haseł nie znać ani nie respektować.

Ogólne i abstrakcyjne teorie o naturze społeczeństw stały się codziennym tematem rozmów wszystkich próżniaków, [...] rozpalały nawet wyobraźnię kobiet i chłopów (Tocqueville, 1994: 156).

Paryż, który coraz bardziej stawał się jedynym mistrzem nauk we Francji, nadawał w końcu wszystkim umysłom ten sam kształt i wspólny styl. [...] Wszyscy stojący ponad ludem byli do siebie podobni; mieli te same myśli, te same przyzwyczajenia, kierowali się samym smakiem, oddawali się tym samym przyjemnościom, czytali te same książki, mówili tym samym językiem (Tocqueville, 1994: 104).

Tymczasem Rousseau łamał ustalone konwencje. Swoim buntem gorszył opinię publiczną. Szokował radykalizmem poglądów. Jego koncepcje były jak broń, która rozsadzała dominujące schematy myślenia i reguły działania. Jak pisał John Stuart Mill:

W osiemnastym wieku, gdy prawie wszyscy ludzie wykształceni i wszyscy idący za nimi ludzie niewykształceni rozpływali się w podziwie dla tego, co nazywali cywilizacją i dla cudów nowożytnej nauki, literatury i filozofii i wielce przeceniając różnice między ludźmi nowożytnych i starożytnych czasów, upajali się przeświadczeniem, że cała ta różnica

stanu, syna kanclerza Francji, pisał: „Nienawidzę możnych, nienawidzę ich stanu, ich bezduszności, ich przesądów, ich małostkowości i ich występków i nienawidziłbym ich jeszcze bardziej, gdybym nimi nie gardził”. Z kolei do Madame Dupin de Francueil, córki marszałka Saksonii, pisał w kontekście oddania do przytułków piątki swych dzieci: „To stan bogatych, Twój stan, Pani, kradnie chleb mych dzieci” (cyt. za: Baczko, 2009: 39).

${ }^{5}$ Owocem wspomnianej pracy intelektualnej les hommes de lettres była Deklaracja praw człowieka $i$ obywatela (1789), uchwalona przez Konstytuantę kilka tygodni po wybuchu rewolucji francuskiej. 
była na ich korzyść - jakim zbawiennym wstrząsem okazały się dla nich paradoksy Rousseau, które wybuchły niby granaty, ruszając z posad zbitą masę jednostronnej opinii (Mill, 1999: 62-63).

\section{POWRÓT NATURY}

Zdaniem Rousseau cywilizacja degeneruje kondycję człowieka we wszystkich możliwych aspektach. Jego ciało staje się wątłe i schorowane. Człowiek cywilizowany w stosunku do pierwotnego jest jak wyeksploatowany ciężką pracą na roli koń pociągowy w stosunku do dzikiego rumaka ${ }^{6}$. Ten proces utraty wigoru szczególnie szybko zachodzi u wyższych warstw społeczeństwa, ponieważ dysponują one środkami pozwalającymi na kamuflaż.

Krzepkość i tężyznę ciała znajdziemy pod wieśniaczą szatą rolnika, nie pod złoceniami dworaka. [...] Człowiek prawy to atleta: najchętniej walczy nago, gardząc nędznymi ozdobami, które by go w użyciu wszystkich jego sił krępowały i których większość po to jedynie wymyślono, by się pod nimi mogła ukryć jakaś niekształtność (Rousseau, 1956a: 13).

Wraz z rozwojem społecznym psuje się również dusza ludzka. Kontakty z innymi zmuszają człowieka do pokory i uległości; „włączając się w społeczeństwo i popadając w niewolę staje się on słaby, lękliwy, uczy się poniżać i płaszczyć” (Rousseau, 1956b: 151). Uprawianie nauki sieje wątpliwości, mnoży pytania: „refleksyjność jest stanem przeciwnym naturze i [...] człowiek, który rozmyśla, to zwierzę zwyrodniałe" (Rousseau, 1956b: 149). Kontakt ze sztuką powoduje, że staje się delikatny, czuły na cudzą krzywdę, wrażliwy na piękno. Tak ukształtowany, niezdolny jest do trudów ciężkiej pracy fizycznej i krwawej walki:

Nasze dusze wypaczały się, w miarę jak nasze nauki i sztuki zmierzały ku doskonałości (Rousseau, 1956a: 15).

Gdy tak dogodności życia się mnożą, sztuki doskonalą, a zbytek rozpowszechnia, ginie dzielność prawdziwa, zanikają cnoty wojenne (Rousseau, 1956a: 32).

Zajmowanie się nauką zdolne jest ducha raczej zmiękczyć i rozhartować niż wzmocnić i zagrzać do czynu. U Rzymian [...] cnota żołnierska wygasała w miarę, jak zaczynali znać się na obrazach [...] i sami sztuki piękne uprawiać (Rousseau, 1956a: 33).

${ }^{6}$ Zob.: „Koń, kot, byk, nawet osioł, mają przeważnie wzrost wyższy, a już zawsze budowę ciała mocniejszą i są odporniejsze, silniejsze i odważniejsze w lasach niż w naszych domostwach: połowę swych zalet każdy z nich traci stając się zwierzęciem domowym i tak to wygląda jak gdyby wszystkie nasze starania o te zwierzęta, całe dobre traktowanie ich i żywienie, robiły z nich tylko jakieś ułomki. Tak samo dzieje się i z człowiekiem” (Rousseau, 1956b: 151). 
Miękki i zniewieściały tryb życia do reszty go rozhartowuje, odbierając mu i odwagę, i siły (Rousseau, 1956b: 151).

Gdybyście nas nie nauczyli żadnej z tych rzeczy, czy bylibyśmy przez to mniej liczni, gorzej rządzeni, dla nieprzyjaciela mniej groźni? (Rousseau, 1956a: 27)

Pozytywnym bohaterem, jaki wyłania się z twórczości Rousseau, jest bezrefleksyjny atleta; siłacz pozbawiony skrupułów, nieodczuwający wzruszeń, który idzie prosto do celu, nie bojąc się śmierci; zaprawiony w boju wojownik, wolny od wyrzutów sumienia, dylematów moralnych, wątpliwości. Jego najważniejsze cechy to: siła fizyczna, hart ducha i uśpienie rozumu. Taka jednostka nie potrzebuje szat ani konwenansów. Jej ciało jest jędrne, zdrowe, kształtne; dusza jest nieskomplikowana, dumna; mowa - szczera, prostolinijna. Bohater Rousseau nie ma nic do ukrycia. W fizycznym i duchowych sensie - jest nagi.

Jego przeciwieństwem jest człowiek, który, kierowany wstydem, maskuje słabości, skrywa przywary, udaje lepszego, niż jest z natury. Obcując z nim, mamy do czynienia z lepszym wariantem jego osoby, autokreacją, a nie z głęboką prawdą o nim.

Uprzejmość wciąż czegoś wymaga, przyzwoitość coś nakazuje; wciąż idzie się za zwyczajem, nigdy za swą własną naturą. Nie śmiemy się już okazać tym, czym jesteśmy [...]. Nigdy więc nie będzie wiadomo, z kim naprawdę się ma do czynienia (Rousseau, 1956a: 13-14).

Dlaczego Rousseau pragnąt, abyśmy objawili się światu w całej prawdzie, skoro był przekonany, że będzie to obraz zatrważający? Filozof był przecież, wbrew rozpowszechnionej opinii, radykalnym pesymistą antropologicznym ${ }^{7}$. Uważał, że za naszymi dobrymi manierami, kosmetykami do makijażu i wyszukanym strojem kryją się negatywne emocje, słabości charakteru i nikczemne zachowania:

Podejrzenia, urazy, obawy, oziębłość, skrytość, nienawiść, zdrada bezustannie czaić się będą pod tą jednostajną osłoną uprzejmości oszukańczej i złudnej, pod tą wychwalaną ogładą (Rousseau, 1956a: 14).

Zanim sztuka urobiła nasze maniery [...], obyczaj nasz był szorstki, lecz naturalny (Rousseau, 1956a: 13).

Mieszkaniec jakichś krain odległych, który by o obyczajach europejskich chciał sobie wyrobić pojęcie według stanu naszych nauk, doskonałości sztuk, wytworności widowisk, gładkości form towarzyskich, ujmującej grzeczności w rozmowach, nieustającego

${ }^{7} \mathrm{Na}$ temat pesymizmu antropologicznego Rousseau zob. Haremska, 2010. 
jakby pokazu życzliwości [...] cudzoziemiec ten [...] musiałby o naszych obyczajach pomyśleć coś dokładnie przeciwnego temu, czym są istotnie (Rousseau, 1956a: 15).

Kultura oferuje szereg narzędzi maskujących brutalną prawdę o świecie natury i o nas jako jego integralnych elementach. Gładzimy chropowate ściany naszego wspólnego domu - z nadzieją, że to kruche upiększenie przetrwa wiele lat i pozwoli nam zapomnieć, kim jesteśmy i skąd pochodzimy. Co jakiś czas jednak na scenę dziejów wdziera się jakiś buntownik i niszczy dekoracje. „Zupełnie jakby ktoś zdarł tapety, które pokrywały Przyrodę, pojawi się nagle [...] czysta i niczym nie zepsuta, prymitywna dzicz" (Ortega y Gasset, 1995: 88).

\section{DEMOKRACJA A FORMY TOWARZYSKIE}

Barbarzyństwo od cywilizacji różni obecność norm. „Nie istnieją normy barbarzyńskie. Barbarzyństwo to brak wszelkich norm i możliwej apelacji. Wyższy lub niższy stopień kultury mierzy się większą lub mniejszą ścisłością norm” (Ortega y Gasset, 1995: 71). Normy kultury, reguły savoir vivre, obyczaje towarzyskie pełnią nie tylko rolę wygodnego kamuflażu, którym moglibyśmy zwodzić otoczenie - jak to widział Rousseau. One są zewnętrznym wymogiem, do którego należy się dostosować. Mają wymiar opresyjny. Respektowanie ich jest trudne, wiąże się z wysiłkiem, lękiem przed społecznymi konsekwencjami. Zastajemy je jako działającą z zewnątrz instancję, która każe nam stłumić naturalne potrzeby i odruchy. Spełniają bardzo ważną rolę w procesie naszego wyłaniania się ze świata zwierzęcych instynktów i dojrzewania jako człowiek.

Reguły dobrego zachowania w różnych ustrojach mają różną rangę. W demokracji moc ich oddziaływania wydaje się mniejsza. Jak zauważa Tocqueville:

Ludzie demokracji nie mają dostatecznego zrozumienia dla przydatności form i instynktownie je lekceważą. [...] Formy wzbudzają w nich pogardę, a nawet nienawiść. [...] irytuje ich najmniejsza zwłoka. W życiu politycznym temperament ów sprawia, że odrzucają formy, opóźniają one bowiem chwilę osiągnięcia celu (Tocqueville, 1976: 476-477).

Demokratyzacja form oznacza obniżenie ich restrykcyjności. W warunkach formalnej równości sztywność obyczajów i ceremonialność zachowań, służące podkreśleniu pozycji każdej ze stron relacji, wydają się zbędne. Relacje są partnerskie, pozbawione pierwiastka władzy i uniżoności, oparte na wzajemnych świadczeniach i sprawiedliwej wymianie.

Jednak i w demokracji mają miejsce jednostkowe różnice, będące tytułem do dominacji. Mimo formalnie równej pozycji wszystkich, również tu są młodzi, 
zdrowi, piękni, utalentowani i bogaci. Bez respektowania norm kultury ich przewagi w uposażeniu indywidualnym ujawnią się i zagrożą fundamentom ustroju. Formy są jedną z instytucji zabezpieczających funkcjonowanie liberalnej demokracji. Tocqueville wymienit je — obok wolnych sądów, niezależnej prasy, oddolnych stowarzyszeń i silnych samorządów - jako konieczny warunek wolności osobistej.

Ponieważ podstawową zaletą form jest to, że wznoszą barierę pomiędzy silnym i słabym, rządzącym i rządzonym oraz wstrzymują tego pierwszego, by drugiemu dać czas na zorientowanie się w sytuacji - właśnie fakt, że formy są niewygodne ludziom demokracji, czyni je szczególne pożytecznymi dla sprawy wolności. Formy są tym bardziej niezbędne, im aktywniejsza i potężniejsza jest władza oraz im bardziej niedołężni i osłabieni są obywatele. Dlatego społeczeństwa demokratyczne potrzebują form bardziej od innych i dlatego mniej je poważają. [...] Formy służą dziś najżywotniejszym interesom ludzkości. [...] W czasach arystokracji oddawano formom zabobonną cześć - my powinniśmy mieć dla nich oświecony i rozważny szacunek (Tocqueville, 1976: 476-477).

\section{NATURALNA NIERÓWNOŚĆ}

Pierwszą reakcją na spotkanie drugiego człowieka jest porównywanie się i chęć wywyższenia. Do głosu dochodzi ten aspekt natury ludzkiej, który Platon nazwat duszą tymotejską (thymos). Thomas Hobbes również dostrzegał w naturze ludzkiej ten pierwiastek: „na pierwszym miejscu stawiam jako ogólną skłonność wszystkich ludzi stałe i nieznające spoczynku pragnienie coraz to większej mocy, które ustaje dopiero ze śmiercią" (Hobbes, 2004: 178). Immanuel Kant mówił o aspołecznej skłonności do rywalizacji ${ }^{8}$, Friedrich Nietzsche - o woli mocy ${ }^{9}$,

${ }^{8}$ Zdaniem Kanta instynktowi społecznemu człowieka towarzyszą tendencje antyspołeczne, rywalizacyjne, ambicjonalne; „przezwycięża on swoją skłonność do lenistwa i gnany ambicją, żądzą władzy lub bogactwa, dąży do zdobycia sobie pozycji wśród bliźnich, których nie może znieść, ale bez których nie może się obyć” (Kant, 1995: 39).

${ }_{9}^{9}$ Według Nietzschego wola mocy przenika wszystkie postaci życia, będąc źródłem ich siły sprawczej. W wypadku człowieka wyraża się wewnętrzną energią, witalnością, hartem ducha, odpornością na przeciwności, gotowością niestrudzonej walki i radością zwycięstwa. Wysoki poziom woli mocy charakteryzuje rasę „panów”, samodzielnie wyznaczających sobie cele, nieliczących się z innymi, pokonujących wszystkie przeszkody na drodze, narzucających światu swą wolę. Nietzscheańscy „panowie” to barbarzyńcy niszczący zastany ład, niebojący się śmierci, gardzący słabością: „nie wiele lepsi, niż wolno puszczone zwierzęta drapieżne. Tam używają zwolnienia od wszelkiego społecznego przymusu, w puszczy wynagradzają sobie wytężenie, powodowane długiem zamknięciem i ujęciem w płoty pokoju, powracają ku niewinności sumienia drapieżców, jako radosne potwory, które może po okropnym szeregu mordów, podpaleń, zgwałceń i znęcań się odchodzą z junactwem i równowagą duchową, jakby spełnili jeno psotę uczniacką, w przekonaniu, że poeci znów na długo będą mieli co opiewać i sławić. Na dnie wszystkich tych ras dostojnych nie należy przeoczać drapieżcy, tej wspaniałej, za zdobyczą 
a Georg Wilhelm Friedrich Hegel — o pragnieniu uznania ${ }^{10}$. Thymos psuje nasze relacje z otoczeniem, do każdego spotkania wprowadza element rywalizacji. Oczekujemy od innych osób uznania naszej wartości, co uzależnia nas od ich ocen i wprowadza do naszego życia nieustanny niepokój. Nie chcemy być równi, pragniemy być lepsi od otoczenia, bardziej znaczący. Potrzeby te inicjują wyniszczający proces relatywizowania własnej wartości.

Zdaniem Rousseau walka o prestiż zaczęła się wraz z zawiązaniem się pierwszych wspólnot ludzkich. Nierówności naturalne, w stanie natury nieistotne, nabrały znaczenia. Pojawili się zwycięzcy i przegrani, a wraz z nimi kolejne emocje zatruwające duszę ludzką. Filozof opisywał ów proces następująco:

Każdy zaczął się przyglądać innym i pragnąć, by i jemu się przyglądano, i uznanie publiczne nabrało ceny. Kto najlepiej śpiewał lub tańczył, kto górował siłą, urodą, zręcznością albo wymową, tego poważano najwięcej; i to stało się pierwszym krokiem ku nierówności, a jednocześnie ku występkom: $\mathrm{z}$ tych pierwszych wyróżnień narodziły się z jednej strony próżność i wzgarda, z drugiej wstyd i uczucie zawiści (Rousseau, 1956b: 194).

W efekcie działania nierówności naturalnych powstały nierówności społeczne, związane z posiadaniem dóbr i władzą polityczną:

silniejszy wykonywał więcej pracy, zręczniejszy czerpał ze swojej większe korzyści; ktoś bardziej pomystowy znajdował sposoby uczynienia jej krótszą [...]; i tak, przy pracy tej samej, jeden ciągnął wielkie zyski, gdy drugi z trudem tylko mógł się wyżywić (Rousseau, 1956b: 201).

Dotychczasowe zmiany generowaty szereg negatywnych emocji, niemniej nie były niesprawiedliwe. Do niesprawiedliwości doszło dopiero na kolejnym etapie, gdy rządzący przekazali swoje bogactwa i pozycję potomstwu; gdy władza stała się dziedziczna. Dzieci w spadku, bez żadnych swoich zasług, otrzymywały majątki i przywileje. Hierarchia społeczna przestała odpowiadać naturalnej. Reguły sukcesji przekreśliły początkowy związek między zasługą i nagrodą, przewagą naturalną i przywilejem społecznym. Według filozofa był to początek degeneracji ludzkości. Taki ustrój - oparty na marnotrawstwie talentów i sił witalnych ludu oraz na niesprawiedliwym uprzywilejowaniu warstw wyższych — skazany jest, zdaniem Rousseau, na upadek:

i zwycięstwem lubieżnie węszącej, płowej bestyi. Dla tego ukrytego podłoża potrzeba co pewien czas wyładowania, zwierzę musi na wierzch się wydobyć, musi znów wrócić do puszczy" (Nietzsche, 1906: 35-36).

${ }^{10}$ Według Hegla spotkaniu dwóch osób zawsze towarzyszy walka o uznanie, władzę, przywództwo. Taki charakter miały już relacje „pierwszych ludzi” u początków ludzkiej historii. Walka kończyła się, gdy jedna strona, lękając się utraty życia, przyjmowała rolę „niewolnika”, zaś druga, gotowa toczyć bój dalej, stawała się „panem”. Zob. Hegel, 1963: 221-228. 
nic śród ludzi nie jest mniej stałe niż owe zewnętrzne stosunki będące częściej dziełem przypadku niż owocem mądrości, a zwane słabością i potęgą, bogactwem i ubóstwem, więc na pierwszy rzut oka urządzenia ludzkie mogą się wydać gmachami wzniesionymi na stosach ruchomego piasku (Rousseau, 1956b: 134).

Gdy runie wreszcie ów gmach, otworzy się przestrzeń do nowego rozdania pozycji i wpływów.

W naturze istnieją różnice. Lepiej przez los uposażeni władają poszkodowanymi w genetycznej loterii. Świat przyrody opiera się na dominacji. Działa siła i zwycięża silniejszy. Odwołanie do brutalnych metod obowiązujących wśród zwierząt jest tradycyjną bronią przeciwników idei równości. Wizja antropologiczna bazująca na doniesieniach nauk przyrodniczych nie stwarza przestrzeni dla idei egalitarnych. Językiem naturalistycznym - operującym takimi kategoriami, jak jak płeć, rasa, inteligencja, tężyzna fizyczna - nie da się wykazać godności jednostki ani dowieść tezy o ludzkiej równości. Odnośnym językiem zwyczajowo głoszono nierówność ludzi i postulat, aby przyrodzonej jakości jednostki odpowiadała jej pozycja w strukturze społecznej. Począwszy od sofistycznej idei rządów silniejszego po Nietzscheańską pochwałe „nadczłowieka”, historia idei pokazuje, że naturalizm prowadzi do panowania jednych jednostek nad drugimi i skazuje słabszych - kobiety, ubogich, klasę ludową, mniejszości etniczne, seksualne, religijne - na pozycje podrzędne.

Rousseau podzielił inklinacje i idiosynkrazje innych naturalistów. Uległ powabowi fizycznej tężyzny i męskiej mocy sprawczej. Odrzucił zastaną cywilizację; na jej gruzach pragnął odtworzyć ład naturalny, oparty na biologicznie uwarunkowanych nierównościach. Pod pozorem walki o równość budował nowe hierarchie.

\section{BIBLIOGRAFIA}

Baczko, B. (2009). Rousseau: samotność i wspólnota. Gdańsk: Słowo/obraz terytoria.

Haremska, K. (2010). Czego się boi Jan Jakub Rousseau? (s. 133-143). W: J. Miklaszewska, P. Spryszak (Red.). Natura ludzka w filozofii nowożytnej i wspótczesnej. Kraków: Wydawnictwo Uniwersytetu Jagiellońskiego.

Hegel, G.W.F. (1963). Fenomenologia ducha (t. 1). (Przeł. A. Landman). Warszawa: Państwowe Wydawnictwo Naukowe.

Hobbes, T. (2004). Lewiatan, czyli materia, forma i wtadza państwa kościelnego i świeckiego. (Przeł. C. Znamierowski). Warszawa: Fundacja Aletheia.

Kant, I. (1995). Pomysły do ujęcia historii powszechnej w aspekcie światowym (s. 35-51). W: I. Kant. Przypuszczalny poczatek ludzkiej bistorii i inne pisma bistoriozoficzne. (Przeł.

M. Żelazny). Toruń: Wydawnictwo Comer. 
Mill, J.S. (1999). O wolności. (Przeł. A. Kurlandzka). Warszawa: Wydawnictwo Akme.

Nietzsche, F. (1906). Z genealogii moralności. (Przeł. L. Staff). Warszawa: Jakub Mortkowicz.

Nietzsche, F. (1990). Wola mocy. (Przeł. S. Wyrzykowski). Warszawa: Bis.

Nietzsche, F. (1995). Tako rzecze Zaratustra. (Przeł. W. Berent). Poznań: Wydawnictwo Zysk i S-ka.

Ortega y Gasset, J. (1995). Bunt mas. (Przeł. P. Niklewicz). Warszawa: Muza.

Platon. (1990). Państwo. (Przeł. W. Witwicki). Warszawa: Wydawnictwo Akme.

Platon. (2002). Gorgiasz (s. 5-124). W: Platon. Gorgiasz. Menon. (Przeł. W. Witwicki). Kęty: Wydawnictwo ANTYK/Marek Derewiecki.

Rousseau, J.J. (1956a). Rozprawa o naukach i sztukach (s. 7-44). w: J.J. Rousseau. Trzy rozprawy z filozofii społecznej. (Przeł. H. Elzenberg). Warszawa: Państwowe Wydawnictwo Naukowe.

Rousseau, J.J. (1956b). Rozprawa o pochodzeniu i podstawach nierówności między ludźmi (111-276). w: J.J. Rousseau. Trzy rozprawy z filozofii społecznej. (Przeł. H. Elzenberg). Warszawa: Państwowe Wydawnictwo Naukowe.

Rousseau, J.J. (1956c). Wyznania. (Przeł. T. Boy-Żeleński). Warszawa: Państwowy Instytut Wydawniczy.

Rousseau, J.J. (1967). Przechadzki samotnego marzyciela. (Przeł. M. Gniewiewska). Warszawa: Czytelnik.

Rousseau, J.J. (2002). Umowa społeczna. (Przeł. A. Peretiatkowicz). Kęty: Wydawnictwo Antyk. Tocqueville, A. de. (1976). O demokracji w Ameryce. (Przeł. M. Król). Warszawa: Państwowy Instytut Wydawniczy.

Tocqueville, A. de. (1994). Stary ustrój i rewolucja. (Przeł. H. Szumańska-Grossowa). Kraków: Społeczny Instytut Wydawniczy Znak. 